\title{
HET STRAFRECHT DER DAJAKS VAN TAJAN EN LANDAK
}

\author{
Door M. C. SCHADEE.
}

\section{$\S$ 1. Privatrechterlijk karakter.}

Reeds herhaaldelijk waren wij in de gelegenheid, kennis te maken met het strafrecht der Landak- en Tajan-Dajaks. Wij zagen, dat het in dezelfde phase verkeert als bij de meeste volken van den Indischen Archipel, daar de straffen een privaat-rechterlijk karakter hebben.

De misdaden worden over het geheel beschouwd niet gepleegd te zijn tegen het algemeen, maar tegen particulieren. ${ }^{1}$

Hier en daar bemerkten wij, dat echter naast dit privaatrechterlijk karakter sommige straffen reeds een publiekrechterlijk karakter verkregen. Zoo moeten sommige boeten aan het $\mathrm{kamponghoofd}$ opgebracht worden wegens overtreding der door hem gegeven bevelen, terwijl andere dienen tot het houden van een offermaaltijd (barimah), waaraan ook de godeu, de verongelijkte partij en diens $\mathrm{k}$ a m ponggenooten deelnemen, tot afwering der kwade invloeden, welke tengevolge der misdaad te duchten zijn. Elders, bijv. in Sumatra heet dit "tot af koeling van den grond" of tot "reiniging van het dorpsgebied".

\section{$\S 2$. Wrakrecht.}

Verder zullen wij in een paar reisverhalen nader kennis maken met de gewoonten der Dajaks van de Batang Atas - de berg-Dajaks van Landak - en zien, dat bij hen het strafrecht op eenen lageren trap van ontwikkeling staat, daar bij deze stammen in sommige gevallen het wraakrecht nog onbeperkt is toegelaten.

1 Zie het Strafrecht bij de volken van het Maleische Ras door G. A. Wilken. Bijdragen tot de Taal-, Land- en Volkenkunde van Ned.-Indië, uitgegeven ter gelegenheid van het Zesde Internationale Congres der Orientalisten 1883. 


\section{§3. Tongkal-instelling..}

Wij hadden ook gelegenheid, reeds te wijzen op het zeer eigenaardige in het Dajaksche strafrecht, hetgeen de beleedigde, wanneer hem naar het volksgeloof onder werking der kwade invloeden een ongeluk overkomt, ook den beleediger nog te dagvaarden voor de schade, welke hij daarmede beloopen heeft.

Het is aan den onwil van den beleediger, om de kwarle rasi's zoo spoedig mogelijk te neutraliseeren, te wijten, dat de ramp plạats had, welnu, dan wordt hij ook als de veroorzaker ervan aangemerkt.

Wij gaan thans over tot de behandeling van eenige nog niet genoemde misdrijveu en zullen zien, dat het wrakrecht ook bij de meer outwikkelde stammen van Laudak en Tajan in enkele gevallen nog is toegelaten.

Tot leiddrand gebruiken wij hierbij de codificatie der adatsvoorschriften der Sĕpatah-Dajaks.

\section{$\S 4$. Doodslag zonder opzet.}

Djika sasaorang mati, tĕrkĕna boenoeh jaug tiada dĕngan sĕngadja dari pada těrsalah pasang děngan sĕnapang atau tĕrsalah parang dĕngan bĕsi atau tĕrboenoeh oleh orang jang gila, mĕlainkan ditimbangnja anam poeloeh anam soekoe, dan tětapi sabĕlomnja dibajar itoe hoekoeman mĕlainkan lěbih dahoeloe mĕmbajar poengoet bĕsi saboewah djempa dan pamabang artinja mĕnanam mandos sĕrta sabidji mangkos poetih dibawah tangga dan tiba-tiba datang sawatoe dari pada soedaranja atau kapalanja sabĕlah orang jang tĕrkĕna boenoeh itoe pada orang jang mĕmboenoeh sampei dia mĕlangkah itoe mandos jang tĕrtanam dibawah tangga itoe, mĕlainkan salah, sapěrti hoekoeman jang anam poeloeh anam soekoe itoe tinggal tiga poeloeh tiga soekoe, maka djika sampè dia mĕmbalas dan mĕmboenoeh, maka mati disablah orang jang didatangnja itoe mĕlainkan tiada djadi dibajar harganja njawa jang mati dahoeloe itoe, dan djika mati sablah orang jang mĕndatangi itoe mĕlainkan tiada boleh dibajar harga njawanja sĕkadar bajar siam pĕngalěboeran baranas mandos sěrta babinja dĕlapan real dan kain tjindai doewa lai.

\section{Vertaling.}

Indien iemand, wie het ook zij, sterft, gedood, echter niet met opzet, bij ongeluk getroffen door een geweerschot of geraakt door een wapen, of gedood wordt door een krankzinnige, dan wordt hij veroordeeld tot zestig realen en zes soekoes boete, 
maar voordat hij die boete betaalt, moet hij eerst de "poengoet bĕsi" uitkeeren, een djempa, en de "pamabang" verrichten, dat wil zeggen een tampajan mandos en een wit kopje onder de trap platsen, en wanneer nu een familielid of kamponghoofd van den verslagene in de woning van den delinquent komt en hij stoort zich niet aau dien tampajan, welke onder de trap geplaatst is, dan wordt hij daardoor schuldig en blijven van die zestig realen zes soekoes slechts dertig realen en drie soekoes te betalen over. Indien hij echter er toe overgaat om wraak te nemen, en er sterft iemand van de partij, welke aangevallen wordt, dan behoeft het wergeld van dengeen, die vroeger stierf, niet uitbetaald te worden, en indien iemand vau de aanvallers sterft, dan behoeft voor hem geen wergeld betald te worden, maar moet slechts een "verzoenings-siam" met een tampajan mandos uitgekeerd worden en een varken van acht reaal en twee stuks lijkkleeden.

Uit het bovenstaande blijkt, dat de Sĕpatah-Dajaks naast de tahil nog eene andere waarde-eenheid kennen, de reaal. Deze gebruiken zij slechts ingeval van doodslag. Bij de Dajaks, waar de reaal de waarde-eenheid is, wordt een pati njawa (ook batang $n j a w a)$ d. i. het wergeld of bloedgeld ${ }^{1}$ voor het dooden van een persoon gesteld op zestig reaal en zes soekoe, hetgeen door de Tĕmila of Sĕpatah-Dajaks overgenomen is.

Het witte aarden kopje en de tampajan mando geplaatst onder de trap van de woning maken den toegang tot de kampoug voor den aanvaller ontoegankelijk, vormen een grens of scheidsmuur, die niet overschreden (di langkah) mag worden.

De poengoet bĕsi is reeds hierboven verklaard.

Wordt de aanbieding van de poengoet b ĕsi en het plaatsen van een wit aarden kopje nagelaten, dan is nog het wraakrecht ten volle toegelaten, en mogen de bloedverwanten van den vermoorde den moordenaar eveneens dooden.

Omtrent de "siam pĕngalěboeran" heet het nog, dat deze dient, om het lichaam, de lijkkleeden om de huid van den verslagene te vervangen.

De mandos komt aan het kamponghoofd en het varken dient tot een offermaal (barimah).

1 Wergeld of weergeld $=$ bloedprijs. Weer $=$ het Gothisehe vair, het Latijnsche vir $=$ man. Wergeld $=$ prijs voor een man. Weerwolf $=$ manwolf. Pati njawa $=$ Het dooden van een njawa. Pati-grondwoord van $\mathrm{mati}=$ dood. Batang njawa =een njawa; njawa = ziel, leven, levensbeginsel. 


\section{$\S 5$. Doodslag bij betrapping op heeterdaad van overspel.}

"Djika ada sawatoe orang laki-laki kadapatan dĕngan saoraug prampoewan, jang soedah ada lakinja, dan lakinja sĕndiri mĕndapatnja, maka itoe si laki mĕmboenoeh kapada madoe moedanja itoe sĕrta bininja, maka mati kadoewanja, maka itoe si laki tiada tĕrkĕna sawatoe apa-apa dan djika madoe moedanja sahadja jang mati di timbang njawanja anam tahil sapoeloeh amas."

\section{Vertaling.}

Indien bij betrapping op heeterdaad van overspel met eene getrouwde, door den echtgenoot dier vrouw zelve, deze zijn medeminnaar en zijne vrouw doodt, dan wordt hij in het geheel niet beboet, mar indien slechts de medeminnaar sterft, dan betaalt hij als diens wergeld zes tahil en tien a mas.

Ook bij de Manjoeké-Dajaks is het wergeld in dit geval zes ta hil.

Wat in het vorig artikel gezegd werd omtrent de "poengoet bĕsi" en de "pamabang" is ook hier weer van toepassing.

Indien de beleedigde echtgenoot slechts een der schuldigen doodt, dan betaalt hij als diens wergeld slechts zes tahil en tien a mas n.l. in geval het overspel bewezen is, bijv. wanneer hij den medeminnaar doodt in zijne eigene (d.i. van den beleedigden echtgenoot) slaapstede, of wanneer hij zijne vrouw doodt en men ziet den medeminnaar wegloopen. In het laatste geval betaalt hij het wergeld der vrouw aan hare familie, maar ontvangt de boete op "prangkat" van den weggeloopen medeminnaar. Sterft de medeminnaar ook, dan betaalt de man geene boete maar ontvangt ook geen "prangkat".

Worden de overspeligen door den echtgenoot in het bosch betrapt en doodt hij slechts een hunner en loopt de andere weg, zoodat hij later het overspel niet bewijzen kan, dan wordt het wergeld op het volle bedrag gebracht.

Verder behandelt de codificatie het geval van eenvoudige verwonding en zware verwonding, welke den dood ten gevolge heeft.

\section{$\S 6$. Verwonding.}

"Djika sawatoe orang mĕmoekoel deri pada anas atau bini atau sanas soedara, apa lagi jang lain orang, djikalau tiada patoet salahnja dipoekoel, mĕlainkan di hoekoem saboewah siam 
saèkor babi dan djikalau sampè loeka bĕrdarah, mĕlainkan di timbang tiga tahil sapoeloeh amas saèkor babi dan djika sampè mati ditimbangnja anam poeloeh anam soekoe."

\section{Vertaling.}

"Indien iemand zijn kind of vrouw slaat, of een bloedverwant, laat staan een geheel vreemde, en hij doet het zonder gegronde reden, dan wordt hij veroordeeld tot eene boete van een siam en een varken en indien de persoon bloedend verwond is, drie tahil tien a mas en een varken en indien deze sterft, zestig real en zes soekoe."

In de Manjoeké-streek wordt verwonding door onvoorzichtigheid beboet met een tampajan siton, een hoen en een stuk ijzer als pangkaras soemangat (versterking van de ziel.)

Zware verwonding met opzet met zes tahil.

Sterft de verwonde, dan wordt de boete twaalf tahil, ook ingeval de dood het gevolg is van onvoorzichtigheid. Twaalf tahil is dus de harga njawa - de prijs van een njawa.

Hetgeen de codificatie voor straf stelt op beleediging, zagen wij reeds boven.

Een bijzonder geval van beleediging is het afsnijden van iemands haar.

"Deri pĕrkara sampong ramboet jang tiada niat hĕndas mĕrdajakan, ditimbang tiga tahil, maka djika memang niat hĕndas mĕrdajakan ditimbang anam tahil sapoeloeh amas, dia moesti toeroet dan moesti bajar."

"Indien iemand een andermans haar afsnijdt, zonder echter booze bedoeling, dan wordt hij veroordeeld tot drie tahil boete, maar wanneer het werkelijk met opzet is om iemand te verderven, dan bedraagt de boete zes tahil en tien a mas. De schuldige moet gehoorzamen en de boete betalen".

Geen opzet wordt bijvoorbeeld verondersteld, wanneer iemand, welke met een ander twistende is, hem in het gevecht een haarlok afsnijdt, zonder deze mede te nemen.

Geschiedt echter de handeling, zonder dat de andere het merkt, en tracht de schuldige het haarbosje te verbergen, of loopt er mede weg, dan is het duidelijk, dat hij daarmede booze bedoelingen heeft, er een toovermiddel van wil bereiden, om den ander ziekte te berokkenen of te doen sterven.

Reeds Dr. G. A. Wilken wees er op, dat de Land-Dajaks van Serrawak het haar soms met de ziel vereenzelvigen. Men leze hier- 
over "Ueber das Haaropfer" in de Revue Coloniale internationale Mai-Juin 1887, blz. 379 en 424.

Ook bij de Koemba-Dajaks komt dit voor.

Verwonding en onwillige berooving van iemands leven door het opstellen van voetangels en vallen wordt in de volgende artikelen behandeld.

"Djika mĕmasang soedas atau soengga atau pĕti, maka soedah ditrangkan kapada orang banjas tiba mĕngĕna orang, djika sakadar pakatang sahadja, tjoema mĕmbajar "sajang darah": těmpajan tĕngah saèkor ajam dan djikalau sampè mati ditimbang njawa tiga tahil sapoeloeh amas, dan djika itoe soedas atau soengga atau pěti soedah djadi tiada ditrangkan kapada orang banjas ditimbang anam poeloeh anam soekoe."

\section{Vertaling.}

"Indien men voetangels of varkensvallen opstelt en hiervan in het openbaar mededeeling doet en iemand wordt er door getroffen, echter slechts gewond, dan betaalt men maar als vergoeding van het bloed een $\mathrm{t}$ a m pajan $t$ ĕngah en een kip, en indien de getroffene sterft, dan wordt de boete drie tahil en tien a mas, maar indien de voetangel of varkensval opgesteld was zonder dat het aan de groote menigte bekend was gemaakt, dan wordt het wergeld zestig real en zes soekoe's."

Soedak en soengga - Maleisch randjau - zijn bamboe spietsen, schuin in den groud gestoken tot bescherming van vruchtboomen of padivelden.

Pĕti (Mal)-pati (Daj.) is een val, bestaande uit een speer verbonden aan een gespannen boog, welke afgat wanneer zij toevallig aangeraakt wordt.

Tiada boleh sakali-kali mĕmasang soedas atau soengga atau pĕti dibawah pohon boewah-boewahan jang ditĕngah djalan běsar atau djalan pěranti orang běroelang-oelangan dan djika dipasang djoega mĕlainkan dihoekoem saboewah siam saèkor babi, maka djika mĕngĕna orang sampè mati, mĕlainkan ditimbang anam poeloeh anam soekoe".

\section{Vertaling.}

"Het is volstrekt verboden voetangels of vallen te plaatsen onder vruchtboomen, welke aan den grooteu weg liggen of aan de zijpaadjes, waar gewoonlijk veel heen en weer geloopen wordt; en indien men het toch doet, dan wordt men beboet met een sia m en een varken en indien iemand er door gewond rakt en sterft, dan betaalt hij zestig reaal en zes soek oe's." 
§ 7. Misdrijven tegen den eigendom. Verbodsmerken.

De misdrijven tegen den eigendom worden in de volgende artikelen behandeld.

"Djoega tiap-tiap jang ada mĕmpoenjai sapohon boewah, jang soedah bĕrboewah katĕngah djalan bĕsar atau djalan jang pĕranti didjalani orang bĕroelang-oelang mĕlainkan tiada boleh didjongko dan $^{5}$ ditikal, maka djika didjongkos dan ditikal djoega barangkali dinais orang tiada boleh didahwa."

\section{Vertaling.}

"Ieder, die reeds vruchtdragende vruchtboomen bezit, staande aan den grooten weg of de zijpaadjes waar gewoonlijk veel heen en weer geloopen wordt, mag aan deze boomen geene verbodsmerken aanbrengen, indien hij het echter toch doet en de vruchten worden weggehaald, dan mag hij geen aanklacht indienen."

Tikal en djongkos zijn verbodsmerken, door wier plaatsing het pantang wordt deu boom te beklimmen. De boom wordt daardoor, wat de Australiërs noemen taboe, d. i. heilig, den goden gewijd. Vooral op overtredingen van tikal- of djongkos-bepalingen is de "atoeran-tongkal" van toepassing. De goede geesten worden daardoor toch in hunne eigene rechten aangetast, beleedigd trekken zij zich terug, de wereld ten spel latende van duivels en daemonen. De kwade rasi's zijn meer dan ooit na dergelijke feiten te vreezen.

De "tikal" bestaat uit een band om den boom gebonden, waartusschen in schuine richting tal van speertjes van bamboe zijn gestoken. De djongkos is een stok of bamboe aan den voet van den boom in den grond gestoken, van inkervingen voorzien, gelijk een Dajaksche trap.

Door Maleiers gebezigd is zij anders gevormd, namelijk zonder inkepingen, mar in een scherpe punt uitloopend. De djongkos van den $\mathrm{Radja}$ is echter an het uiteinde in tweeën gesplitst met horizontaal dwarshoutje tusschen de uitstaande beenen.

"Djika ada sapohon boewah jang soedah bĕrboewah maka ada pagarnja, dan didalam pagar itoe ada bĕrsoeda ${ }^{5}$ atau soengga atau pěti dan dikasih tanda lagi soepaja orang tahoe dan soedah ditrangkan lagi kapada orang banjas, tiba-tiba ada saorang mĕngambil itoe boewah, maka tĕrkĕna itoe soedas atau soengga bai pěti, jang didalam pagar itoe sampè mati, mĕlainkan tiada boleh didahwa." 


\section{Vertaling.}

"Iridien een vruchtboom, welke vruchten draagt, omgeven is door eene omheining en in die omheining zijn randja u's en vallen opgesteld, en er is nog een teeken bij aangebracht, opdat iedereen het wete en het is aan iedereen bekend gemaakt, wammeer dan iemand nog die vruchten weghaalt en hij wondt zich an die randja u's of die val, binnen de omheining, dan mag hij geeue klacht indienen."

Door de omheining van het terrein onder een gedjongkokten boom strekt zich het verbod ook tot de afgevallen vruchten uit. Het teeken voor het aanwezig zijn van randjau's en pĕti's is een kruis van bamboe-stokken in den vorm van een $X$ (St. Andries-kruis, crux decussata) aan hest boveneinde van een in den grond staanden stok gebonden, vóor de plaats, waar de randjau's gelegen ziju.

Dan lagi tiada boleh mĕndjongkos dan mĕnikal batang boewah atau batang sĕmpoewan orang, jang boekan kita sĕndiri poenja, djika mĕndjongkos mĕnikal batang boewah dan sĕmpoewan orang, kĕna hoekoem saboewah siam saèkor babi".

\section{Vertaling.}

"En voorts mag iemand aan geen vruchtboom of boom, waarin zich een bijennest bevindt, verbodsteekenen aanbrengen, indien deze niet zijn eigendom is, indien men verbodsteekenen annbrengt in een andermans vrucht- of bijenboom, dan wordt men beboet met een siam en een varken."

Het is echter niet verboden, wanneer men het doet met toestemming van den eigenaar of de eigenaars.

Gewoonlijk hebben vruchtboomen meerdere eigenaars, bijv. de oudste dochter met hare broeders en zusters of soms neven en nichten.

De straf op het aanbrengen van verbodsmerken wordt zwaarder, indien men in het geheel niet tot de medegerechtigden (waris) behoort.

"Djika sawatoe pohon boewah jang ditikal dan didjongkos dĕngan atoeran, maka boewahnja poen sědang dimakan, maka dinai ${ }^{s}$ oleh sĕgala orang jang tiada mĕmbilang tahoe kapada orang jang poenja, mĕlainkan kĕna hoekoem tĕmpajan tĕngah".

$$
\text { Vertaling. }
$$

"Indien eeu vruchtboom volgens de regels is gedjongkokt en de vruchten rijp genoeg om gegeten te worden, en hij 
wordt door iemand beklommen, die dit niet aan den eigenaar heeft gezegd, dan wordt die persoon beboet met een tĕmpajan t ĕng a h".

Dit "beklimmen" heeft natuurlijk de beteekenis vau "de vruchten af halen".

De bepalingen omtrent de tikal en djongkos-voorschriften zijn zeer onvolledig, de "codificatie" geeft niet meer, hetgeen wel te betreuren is. Zoo komt er geene bepaling in voor omtrent het weguemen van verbodsteekenen, hetgeeu ook strafbaar is. Evenmin komt in de bovenstande artikelen uit, dat juist de a to e ra n tongkal bij deze soort misdrijven streng toegepast wordt.

Het is ook jammer, dat in deze codificatic niets te vinden is omtrent verbodsmerken op gronden, die men bebouwen wil. De daaromtrent bestaande bepalingen zijn zeer belangrijk, vooral in de Manjoeké-streek. In de praktijk zijn zij daar van veel belang, daar de Dajaks er dicht op elkaar wonen en de geheele uitgestrektheid van den grond voor rijstcultuur gebruikt wordt. Twisten over grondeigendom zijn er aan de orde van den dag.

Strafbar is het op een stuk land, waarop men geene rechten heeft, verbodsmerken aan te brengen. Ook deze verbodsmerken heeteu $\mathrm{dj}$ o n g k os. Beboet wordt hij die een andermans d jo $\mathrm{ng} \mathrm{k} \mathrm{os}$ wegneemt. Ook hier geldt de atoeran tongkal, bij weigering de boete te betalen.

In beide gevallen wordt ook de boete zwaarder, wanneer men niet tot de deelgerechtigden behoort, of ook wanueer men met het bebouwen van het rijstveld doorgaat, nadat de eigenaar zulks reeds verboden heeft.

Bij het bebouwen van den grond van een ander brengt men huur op. Alle Dajaks van Landak noemen die huur sasi ${ }^{1}$.

1 In de Molukken beteekent sasi: „door een verbodsmerk gewijd, ontoegankelijk," wat elders in den Archipel ook „p ěma li" heet, en wat de LandakDajaks meestal "pantang" noemen.

Zie over het aanbrengen van verbodsteekenen nog „Eenige aanteekeningen op de Ethnographie van Flores" door C. M. Pleijte Wzn., Indische Gids, 1890, deel II pag. 2582. Centraal Selebes - door Riedel, Bijdragen, volgreeks V, deel I pag. 88-95. De Godsdienstbegrippen der Halmaherasche Alfoeren, Tijdschrift voor Indische Taal-, Land- en Volkenkunde, Deel XXVII pag. 450.

Over Taboe lees het artikel van Frazer in de Encyclopaedia Brittanica, "taboo".

Naast "tikal" hoort men door Maleiers aan de Kapoeas ook het woord "pang gor" gebruiken.

In Mĕliau gebruikt men koor "verbodsmerk" de woorden adjam en klombong. Adjam is een stok vlak bij den boom in den grond gestoken, in schuine richting naar den boom wijzende, de klombong wordt gevormd door takken met bladeren om den boom gebonden. 
Boete staat op het beschadigen en vernielen van vruchtboomen, op grond, dien men bebouwen wil. De waarde der vernielde boomen moet bovendien vergoed worden.

Van belang is het, hier nog eens te herlezen wat Wilken over het taboe zegt in zijne verhandeling over het Pandrecht bij de Volken vau den Indischen Archipel. [Bijdragen tot de Taal-, Land- en Volkenkunde van N.-I., volgreeks $V$, deel 3, blz. 559].

Eenige bijzondere gevallen van diefstal worden behandeld in het volgende artikel:

"Djika saorang mĕntjoeri sampala tahoen, atau batoe asahan, atau mĕntjoeri kadangau padi atau kapabrasan atau mĕntjaboet klangkang dapat hoekoem saboewah siam saèkor babi, maka djika měntjoeri kadjongko ${ }^{s}$ pamarangan atau kaboeboe kasoekan 1

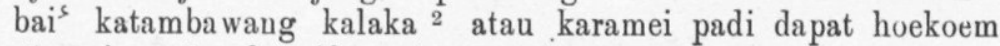
tĕmpajan tĕngah saèkor ajam."

\section{Vertaling.}

"Indien iemand, wie ook, de eerstelingen van den rijstoogst of een slijpsteen, of padi of rijst uit de bergplaatsen steelt, of een klangkang uittrekt, krijgt hij eene boete van een siam en een varken. Ingeval iemand steelt van al wat gedjongkokt is of wat in fuiken gevangen is, of in de ta mbawang, (kam pongerf met vruchtboomen) of op de oude ladang velden ${ }^{3}$, wordt hij beboet met een tampajan tĕngah en een hoen."

De slijpsteen staat bij de Dajaks in bijzondere bescherming, welke wellicht verband houdt met de vereering van het ijzer en staal. Het laatste wordt toch steeds op den slijpsteen gewet.

"Batoe asahan toewa deri bĕsi" 4 zegt de Dajak. Vergelijk wat Grabowsky mededeelt over de vereering van den slijpsteen. 5

Diefstal in huis wordt veel zwaarder gestraft dan met een siam

1 Soekan =tĕkaras $=$ een soort fuik.

${ }^{2} \mathrm{Kalaka}=$ tambawang=en verzameling vruchtboomen, het erf om de kampong-woning met vruchtboomen beplant.

3 N.l. die beplant zijn met tweede gewassen, cassa ve, suikerriet, $\mathrm{kla}$ d i etc.

"Deze zin kan vertaald worden: "De slijpsteen is ouder dan ijzer" - of "de slijpsteen is de vader van het ijzer" of „de slijpsteen is het ijzer tot heil -

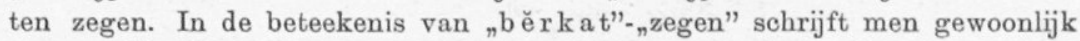
"toewah". Toch is het hetzelfde woord. Al wat "oud" is, is volgens algemeene opvatting ook "zegen aanbrengend".

${ }^{5}$ Ueber Äusserungen geistigen Lebens bei den Olo ngadju in Süd-Ost Borneo, Bijdragen tot de Taal-, Land- en Volkenkunde van Ned.-Indië, volgreeks 5 , deel 4, pag. 147 . 
en een varken. Naar omstandigheden zes tahil en tien a mas of meer. Op diefstal met geweld gepleegd of roof staat twaalf tahil en tien a mas. Steeds met teruggave der gestolen goederen of restitutie van de warde er van.

Ook het stelen van te veld staande padi wordt zwaar gestraft. Bij de Manjoeké-Dajaks met drie en een half tahil, waaronder een siam, verder een varken, een hoen en een stuk ijzer.

De straf is zwaar, omdat de rijst ten eerste moeielijk tegen diefstal te beschermen is en ten tweede van wege de heiligheid van de rijst. Zoo ook staat een zware straf op het opgraven en stelen van aardvruchten (kribang), bij de Manjoeké-Dajaks een tampajan tĕngah, een hoen, een stuk ijzer en baras banjoe (gezalfde rijst).

\section{$\S 8$. Over het verschaffen van eigen recht.}

Over het verschaffen van eigen recht bij schuldvorderingen spreekt het volgende artikel :

"Djikalau sawatoe orang mĕngambil barang orang samantara pĕrkara, maka dia ambil kabělakangnja atau dihadapannja jang tiada dĕngan kasoekaän hatinja sěrta bĕlom mĕngadoe kapada toewanja, maka dapat hoekoem saboewah siam saèkor babi, dan orang jang diambil barangnja itoe poen mĕngoekoem saboewah siam saèkor babi, maka djika dia mongkir, djika sampè mati orang jang diambil barangnja itoe poen měngoekoem saboewah siam saèkor babi, maka djika dia mongkir, djika sampè mati orang jang diambil barangnja itoe karĕna mĕndjadi tongkal didalam pĕrkara rampas itoe, ditimbang njawa tiga tahil sapoeloeh amas bĕrkapalakan djempa adanja”.

\section{Vertaling.}

"Indien iemand iets van een ander weghaalt, tijdens hij een schuldzaak met dien persoon heeft, en hij haalt het achter zijn rug of voor zijn neus weg, maar niet met diens goedvinden en zonder zich eerst bij het hoofd beklaagd te hebben, dan betaalt hij (an het hoofd) eene boete van een siam en een varken en aan den persoon, van wien hij iets in beslag genomen heeft ook een siam en een varken, maar indien hij weigert en indien de persoon, van wien hij iets weggenomen heeft, sterft om reden dat het "tongkal" geworden is gedurende die rampas-zaak, dan moet hij diens wergeld betalen, drie tahil en tien amas met een djempa als eerste voorwerp" .

Deze strafbepaling voorziet in het geval, dat iemand zich zelven recht wil verschaffeu in een schuldzak door beslag te leggen op 
een deel der bezittingen van den schuldenaar, zonder medeweten en toestemming van het $\mathrm{kamponghoofd.} \mathrm{De} \mathrm{straf} \mathrm{hierop} \mathrm{is} \mathrm{niet}$ zwaar en veel minder dan op diefstal, doch wie haar niet oumiddelijk betaalt loopt gevaar, dat bij een sterfgeval ten huize van den gelaedeerde een eisch tot het betalen der tongkal papanga tegen hem ingesteld worde.

Bij de Manjoeké-Dajaks is de straf op dit misdrijf zes tahil met een sia m als hoofdvoorwerp.

\section{$\S 9$. Bedrog.}

De straf op bedrog wordt behandeld in de volgende artikelen.

"Djika wantjana ', artinja sasaorang jang pandei mĕmboewat pĕtenna ${ }^{2}$ kapada lain orang, dapat hoekoeman saboewah siam saèkor babi"l.

\section{Vertaling.}

"Ingeval van "wantjana" dat wil zeggen als iemand wie ook een ander bedriegt, zoo wordt hij beboet met een siam en een varken".

Ander artikel.

$\S 10$. Valsche beschuldiging, ongerechte eisch.

"Pĕrkara boengkal moelang, artinja mĕnageh atau mĕnantang pĕrkara, sabageinja pĕrkara dan pĕrtagèhan, maka sabělomnja poetoes itoe pĕrkara maka dibrĕntikannja oleh orang jang mĕngadjas pĕrkara itoe dan mĕnagèh orang jang tiada bĕroetang, maka dikĕnakan hoekoeman paras gantang".

\section{Vertaling.}

"Terzake van boengkal moelang ${ }^{3}$, dat wil zeggen "het instellen van eene schuldvordering tegen iemand of het inbrengen van een klacht, in wat voor zaak of schuldvordering het ook zij, waarbij de klacht of schuldvordering, voordat er eene beslissing is genomen, ingetrokken wordt door dengeen, die de zaak aanbracht of de schuldvordering instelde tegen iemand,

$1 \mathrm{Wantjana}=$ Skr. wantjana $=$ Mal. bĕntjana $=$ bedriegelijke streken (Wdbk Pijnappel).

2 Pĕtenna=tipoe= = bedrog. Maleisch zegsman. - Het is eene verbastering van het Arabische

(JUXNBOLL).

${ }^{3}$ Boengkal (=bongkal) kw. woengkal, steen =tahil, een goudgewicht (Pijnappel).

Boengkal dus= boete. Boengkal moelang=de boete keert, wordt in plaats van den beschuldigde, den beschuldiger opgelegd. 
die geen schuld heeft, dan wordt de oorspronkelijke eischer of beschuldiger tot de "p a ras gantang" ${ }^{\mathbf{1}}$ veroordeeld, (dat wil zeggen zooveel boeten hij eischte of schuld hij vorderde moet hij zelf betalen).

\section{$\S 11$. Overtredingen tegen de gestelde machten.}

Overtredingen tegen de gestelde machten of van deze tegenover de onderdanen worden behandeld in de volgende artikelen.

"Djikalau sawatoe deri pada anas boewah kampong laki-laki atau prampoewan lari kapada kampong lain, sěbab ada sakit hati, mĕlainkan dihoekoem oleh toewa jang didatanginja itoe saboewah siam saèkor babi dan toewa jang ditinggalkannja itoe poen mĕngoekoem djoega kapadanja saboewah siam saèkor babi".

$$
\text { Vertaling. }
$$

"Indien een der iugezetenen van eene kampong, hetzij man of vrouw naar eene andere $\mathrm{kampong}$ vlucht, om reden dat hij wrok koestert, dan wordt hij door het hoofd der kampong, waarheen hij zich begaf, veroordeeld tot eene boete van een siam en een varken, en ook het hoofd der kampong, van war hij wegliep, beboet hem met een siam en een varken".

\section{Ander artikel.}

"Djika sawatoe deri pada gapit ${ }^{2}$ pasirahnja ${ }^{3}$ atau ana ${ }^{5}$ boewah kampong mĕmboewat sawatoe apa-apa pěkĕrdjaän atau pĕrboewatan bais atau djahat, maka tiada tĕrlěbih dahoeloe moepakat dengan toewa pĕndjĕnangannja dapat hoekoem saboewah siam saèkor babi".

\section{Vertaling.}

"Indien een der mindere hoofden, of een der onhoorigen het een of ander feest aanlegt of iets onderneemt, hetzij goed of kwaad, maar niet van te voren overleg pleegt met het hoofd van de pandjanangan (distrikt), dan wordt hij veroordeeld tot eene boete van een siam en een varken".

\section{§ 12. Beschádiging van tuinvruchten en gewassen.}

Voor de praktijk vooral in de Manjoeké-streek zijn nog van belang

1 Paras gantang = afstrijken van de maat, gelijk maken.

2 Gapit $=$ Mal. kapit - van apit = zich aan weerskanten van iemand bevindend, zooals de raadslieden van den vorst. (Pijnappel's woordenboek).

s Pasirah - van sirah $=$ hoofd (Dajaksch). 
de bepalingen omtrent het beschadigen van tuinvruchten en gewassen door huisdieren.

Indien men een varken daarmede bezig ziet en men waarschuwt den eigenaar, dan is men gerechtigd het varken te dooden. Men moet daarvan dan echter onmiddellijk kennis geven aan het $\mathrm{k}$ a m p o n ghoofd en is dan zelfs gerechtigd, om indien de schade van eenige beteekenis is, de helft van het varken voor zich te houden. Geeft men echter geen kennis aan het $\mathrm{kam}$ pon ghoofd, dan moet men het varken vergoeden.

Doodt men het varken niet, dan blijft alleen de vordering bestaan op vergoeding der toegebrachte schade. (Manjoeké-Sĕtolo).

\section{$\S 13$. Straffen.}

Uit het voorgaande is gebleken, dat de straffen bij de Landaken Tajan-Dajaks alleen zijn vermogensstraffen, d. e. boeten en schadeloosstellingen.

Doodstraf werd door deze Dajaks zoover hui geheugenis reikt nimmer toegepast, en werd dus stellig in geen vijftig jaar voltrokken. Wel staat de doodstraf op bloedschande, maar niemand herinnert zich, dat zulk een onnatuurlijk misdrijf ooit plaats had.

Wij beschouwen natuurlijk mauslag, waar het wraakrecht dit toelaat, niet als een ten uitvoer gebrachte doodstraf.

\section{§ 14. Bewijsmiddelen. Ook in civiele zaken.}

Hieromtrent hebben wij nog slechts weinig mede te deelen. De bewijsmiddelen ziju bekentenis, getuigen-verklaringen, aanwijzingen en godsoordeelen.

De eed kent de Landak- en Tajan-Dajak alleen als dienende ter bezegeling eener belofte voornamelijk bij verzoeningen.

Godsoordeelen worden niet alleen gebezigd tot aanwijzing van het vaderschap, maar ook tot uitwijzing van het recht in burgerlijke zaken, vooral waar het betwisting van den eigendom op ouroerende goederen als vruchtboomen, bijenboomen en oude rijstvelden betreft.

Vooral omtrent t ĕng k a w a n g-boomen, welke vaak gedurende verscheidene jaren geen vrucht dragen en droge rijstvelden, die soms wanneer de grond mager is, tot tien twaalf jaren braak liggen in welken tijd de eigenaars zich niet om hunue bezittingen bemoeien komen vaak geschillen voor.

D1. 66 . 
Beloven de tĕngkawang-boomen eenen goeden oogst af te werpen, dan gaat het $\mathrm{kam}$ ponghoofd van iederen boom den eigenaar na. Waar de eigendom betwist wordt en niet door getuigen uit te maken is, gelast hij een godsoordeel. Gewoonlijk bezigt men dat, hetwelk bestaat in het trekken van een bamboe-pijltje uit een viertal, waarvan er twee voorzien zijn van weerhaken en twee niet. Een der partijen trekt onder het aanroepen der dew a a 's, hen verzoekende den rechthebbende door het godsoordeel te willen aanwijzen. Wie een pijltje trekt met een weerhaak wint de zaak, de andere verliest.

\section{$\S 15$. De rechters.}

De rechtspleging berust facto bij de Dajaksche hoofden.

Het vigeerend politiek contract tusschen Radja en Gouvernement luidt echter geheel anders.

Artikel 20 van het Landaksche contract zegt: "Behoudens de uitzonderingen in het tweede lid van dit artikel vermeld, zijn allen, die zich binnen het gebied van Landak bevinden, onderworpen aan de rechtspraak der rechtbanken en rechters van het Gouvernement.

Zoolang daaromtrent door het Gouvernement niet anders is voorzien, worden buiten de plaatsen waar Gouvernementsambtenaren gevestigd zijn of mochten worden, door den radja of de door hen aangestelde hoofden berecht:

$1^{\circ}$ burgerlijke geschillen over eene waarde van niet meer dan f 50.- tusschen onderdanen van Landak onderling;

$2^{\circ}$ zoodanige overtredingen, door onderdanen van Landak gepleegd, als ingevolge de in de Residentie Westerafdeeling van Borneo vigeerende wettelijke bepalingen behooren tot de bevoegdheid van den politie-rechter (magistraat) met uitzondering van die op het stuk van 's lands middelen en pachten, etc.

Ter nakoming van dit contract grijpt daarom, bijna uitsluitend in geval van moord, de Panambahan onder den drang der Gouvernementsambtenaren in den gewonen loop der zaken in, laat den dader gevangen nemen en levert hem aan het Gouvernement uit. De zaak wordt dan verder berecht door de Gouvernementsrechtbanken, zeer tegen den wensch der bevolking in, die hoegenaamd geene voldoening vindt in een rechtspraak, die niet in de eerste plaats er op uit is den beleedigde schadeloos te stellen em hem te vrijwaren voor de gevolgen der booze invloeden, welke door het misdrijf heeten opgewekt te zijn. 
\$16. Het sluiten van vrede navijandelijkheden (sneltochten) der stammen onderling.

Zijn de vijandige stammen geneigd vrede te sluiten (b ĕ r ta ma ${ }^{s}$ ), dan bieden de Maleische hoofden, òf de $\mathrm{Panambahan}$ òf de Gouvernementsambtenaren hunne hulp aan, om hen te verzoeneu. Door hunne bemiddeling worden dan de vredeteekenen (tanda bĕrbaitan) gewisseld. Deze teekenen zijn: een tampajan mando en een aarden kopje (mangkos) om dien tampajan te dekken.

Partijen worden bij elkaar gebracht, de eerste maal liefst op neutraal terrein en eene plechtige ontmoeting heeft plaats. De daartoe behoorende ceremoniën zullen wij elders beschrijven. Na afloop daarvan worden de boeten geregeld.

De verschiliende soorten te betalen boeten zijn:

\section{$\S 17$. Het wergeld.}

$1^{\circ}$. De pati-njawa - het wergeld, de bloedprijs voor elken gesuelden kop. Deze wordt opgebracht door den geheelen stam, welke zich aan snellen ( $\mathrm{mangajau}$ ) heeft schuldig gemaakt en uitgekeerd an de familie vau den verslagene. Is wederzijds gesneld, dan moet ook wederzijds het wergeld betaald worden. Het bedraagt twaalf tahil. Twaalf verschillende lichaamsdeelen en zintuigen van den gesuelde moeten toch vergoed worden ${ }^{1}$.

Onder die twaalf tahil moeten bij de Manjoeké-Dajaks voorkomen :

een siam;

een tampajan tadjau;

een gong;

een lila;

een so ebang;

een panding van goud;

een streug laugkeh, allen gedekt door een pinggan (aarden bord); uegen stuks tampajan boedoe gedekt door mangkok's (aarden kopjes);

twaalf pinggan daun tangkai ${ }^{2}$ soeman ${ }^{3}$.

1 Vergelijk Senn van Basel, De bloedprijs der Dajaks op Borneo's Westerafdeeling. Tijdschrift van Ned.-Indië 1874. Deel II, pag. 37-38.

2 Tangkai $=$ steel of oor.

${ }^{3}$ Soeman $=$ bamboekoker met kleefrijst. 


\section{$\S 18$. De poengoet baai.}

$2^{\circ}$. de poengoet basi of pamoengoet basi: een siam, een babaudih en een gong. De babandih als lakar of alas dat is als onderstuk om de siam op te doen rusten, de gong om de siam te dekken.

Deze boete wordt even als alle volgende alleen betaald door dengeen, die de vijandelijkheden geopend heeft [mamboeka basi of manoebah]' ${ }^{1}$.

Op het snellen ${ }^{2}$ staat afgezien van het betalen van de bloedprijs geene boete, wanneer het dient om wrak te nemen over eene pas plaats gehad hebbende snelpartij.

\section{$\S 19$. De sangga parang.}

$3^{\circ}$ de sangga parang of pĕnjangga parang, iets dat dient tot tegenhouden van de parang (houwer, kapmes). Evenals de poengoet basi is het een schuldbekentenis door welks aanbieding de tegenpartij voor goed van het nemen van weerwraak moet afzien.

Het is eene bevestiging vau de poengoet basi.

De sangga parang bestat uit een lila.

\section{$\S 20$. De palangkah.}

$4^{\circ}$ de palangkah of pangalangkah (= overschrijding) is de boete wegens overtreding der instellingen welke het snellen verbieden. Zij bestaat uit een djampa, een babandih en een gong. De eerste twee stukken, vervallen aan den radja, de tweede aan het Maleische hoofd (pa mbakal).

\section{$\S 21$. De panoebah.}

$5^{\circ}$ de panoebah is de boete wegens het manoebah, dus kan gelijk gesteld worden met de palangkah. Zij bestaat uit een siam met een tampajan mandos en eeu gong. De siam moet bovendien gedekt zijn door een babandih en staan op een tjanang.

1 Mamboeka basi=het openen van het ijzer d.i. het ontblooten van het $\mathrm{zwaard}$. Manoebah= verbreken der eed. Waarschijnlijk staat dit woord in verband met soebah - de groote eed, na verzoeningen afgelegd.

2 Snellen = mangajau. Gesneld = dikajau. 
De panoebah vervalt aan het Dajaksche hoofd van den stam, waarbij gesneld is.

\section{$\S 22$. De panjasa hoetan.}

$6^{\circ}$ de panjasa hoetan $=$ het reinigen der aarde. Het woord hoetan (= bosch) wordt in Laudak vaak synoniem gebruikt met tanah (land) of nĕgri (landstreek). De panjasa hoetan dient om de kwade rasi's te bezweren, het onheil aanbrengende onschadelijk te maken. ${ }^{1}$

Ook door het snellen toch als door elk ander misdrijf wordt het land panas, aan verderfelijke invloeden onderhevig.

De panjasa hoetan bestaat uit voorwerpen, welke te zamen anderhalf tahil waarde hebben, benevens een varken voor het barimah eu een stuk ijzer als pa:: gkras soemangat (versterking der ziel).

De bedoelde voorwerpen moeten bij voorkeur zijn een tampajan mandos en twee tampajan's boedoe (een klein soort tampajan).

$\mathrm{Na}$ afloop van het wederzijdsch uitkeeren der boeten wordt de onder Dajaks gebruikelijke groote eed (s o ebah) afgelegd.

\section{$\S 23$. Een verzoeningsfeest bij de Sĕpatah-Dajaks.}

De eerste ontmoeting tot verzoening van vijandelijke stammen heeft, zooals wij boven zagen, op onzijdig terrein plaats, bijvoorbeeld ten huize van den persoon, die zijne bemiddeling heeft aan: geboden. Op deze bijeenkomst wordt de eed afgelegd, den vrede niet meer te zullen verstoren, de verschillende boeten worden uitgekeerd en verschillende plechtigheden hebben plaats, om de booze invloeden te paralyseeren.

Later moeten de stammen elkaar ook wederzijds bezoeken in hunne woningen. De mannen van den eenen stam worden daarbij feestelijk onthald in de $\mathrm{kampongs}$ van den anderen en later omgekeerd. De ceremoniën tot het afweren der kwade rasi's worden daarbij herhaald. Deze bijeenkomsten worden soms jaren lang uitgesteld, eerst wanneer de oogst goed uitgevallen is, gaat men er toe over, den anderen stam tot het gebruikelijke bezoek uit te noodigen.

Zoo moesten de Sangking-Dajaks, welke in Mampawa thuis behooren, nog een bezoek brengen aan de Sĕpatah-Dajaks. Zij hadden

1 Vergelijk de uitdrukking panjasa hoetan met „pĕmbasoeh doesoen" in Wilken, Strafrecht bij de volken van het Maleische ras blz. 112. 
als vijanden tegenover elkaar gestaan in de Mandhor-onlusten, warin zich vooral de Semerowa.Dajaks onder $\mathrm{Pa}$ Goenang geweerd hadden.

De datum van het bezoek was vastgesteld op 8 September - het was in het jaar 1892 - en wij begaven ons om er bij tegenwoordig te zijn een paar dagen te voren van Ngabang op reis naar k m pong Bangsal, de hoofdplaats der Sĕpatah-streek. Daar vernamen wij, dat als plaats van ontvangst der Sangking-Dajaks het huis van den Toemĕnggoeng van Saham, het stamhoofd der zuidelijke SĕpatahDajaks was aangewezen. Op weg daarheen zouden de Sangking-Dajaks echter eerst overuachten in de woning van het stamhoofd der noordelijke Sĕpatah-Dajaks, Pakoe Nĕgara, hoofd van kampong Trap.

Wij gingen dus naar kampong Trap, waar Pakoe Nĕgara ons feestelijk iuhaalde. De wanden der voorgalerij waren op Maleische wijze met bonte gordijnen (tabir) behaugen. Verder waren vijf djampa's en vijftien agongs ten toon gespreid en eenige tawaktawaks. Op cen feestdag toch moet men zijn rijkdom aan de gasten laten zien.

Den vorigen dag had Pakoe Nĕgara onder het barimah met een paar hoenderen reeds aan de dewata's kenuis gegeven, dat de Sangkings in antocht waren tot het vieren van een verzoeningsfeest in de kampongs der Sĕpatah-Dajaks, daarbij hun zegen en hulp over deze onderneming afsmeekende.

De Sangkings bleven lang uit, kennelijk verkeerde Pakoe Nĕgara in onrust of zij werkelijk wel komen zouden. Hoe vaak gebeurt het niet, dat een ongeluk voorspellende kéto s vlak voor den aan het hoofd loopenden reiziger heen strijkt; zulk een ongeluk voorspellend voorteeken zou toch in staat zijn de Sangkings weer voorloopig huiswaarts te doen keeren om eerst de kwade rasi's te bezweren.

Den volgenden morgen kwam bericht, dat de Sangkings overnacht hadden in Sebadoe, des middags kwamen zij ook te Trap aan. Zij waren onder de hoede van een Maleisch hoofd, een zekeren kjahi. Het hoofl der Sangkings heette Patih, een titel die tegenwoordig in Landak niet meer in gebruik is, als zijnde van te groot aanzien en gewicht.

Pakoe begaf zich met volgelingen naar buiten de Sangkings te gemoet, om hen in te halen. Bij de eerste ontmoeting hadden onmiddelijk ceremoniën "plaats tot afwering der booze rasi's. Een der Sangking-Dajaks had een wit aarden kopje met olie in de hand, waarin een paar zilveren ringetjes lagen. 


\section{$\S 24$. Ceremonie "pasilo" genamd.}

Met een kippeveer smeerde hij wat olie bij zijne landslieden op het voorhoofd, daarbij gebeden prevelende aan de dewata's (bapatja). Deze ceremonie heet pasilo.

Pakoe bestrooide hen rijkelijk met gele rijst; een terzijde opgesteld orchest van gandang, $\mathrm{tawa}-\mathrm{tawa} \mathrm{a}^{\mathrm{c}}$ en breng-breng deed zich hooren. In optocht trad men de woning van Pakoe binnen, alwaar men tot het barimah met een varken en een kip overging.

Des avonds bespeelden eenige jonge lieden de kromong (da u), anderen spreiden daarbij hunne vaardigheid in het menariën (inlandsche dans) ten toon.

Den volgenden morgen begaven wij ons allen over Bangsal, waar Ja Dimboel (de apanage-houder) en zijn broeder Goesti Ali zich bij ons aansloten naar kampong Saham. (Cf. § 27).

De Toemĕnggoeng van Saham met volgelingen wachtte de SangkingDajaks op, om hen feestelijk in te halen.

De Sankings reikten bij de ontmoeting het door hen medegebrachte aarden kommetje met olie en de twee zilveren ringen, benevens een wit hoen aan den Toemĕnggoeng over. De Sĕpatah-Dajaks beantwoordden dit geschenk door het aanbieden van een tampajan mandos. Rijkelijk bestrooide de Toemĕnggoeng allen met gele rijst, hen welkom toeroepende.

Het bestrijken met olie (pasilo) had toen plaats, thaus echter wederzijds, de Sangking-Dajaks bij de Sĕpatahs en omgekeerd. Het wit aarden kommetje was volgens den uitleg, dien men ons van de ceremonie gaf, een teeken van vrede en goede gezindheid, het ringetje - zonder eind of begin - van de bestendigheid ervan. ${ }^{1}$

1 In het algemeen spreken de Dajaks, bij het aanbieden van ringen, den wensch uit, dat de eigenschap van den ring - het hebben van geen einde ook het deel zal zijn van de tali njawa (= levensdraad) van den persoon, die den ring krijgt.

Men heeft daarbij weer niet in de eerste plaats aan symboliek te denken, maar aan het geloof in sympathetische werking. Men is overtuigd, dat de eigenschap van den ring op de tali-njawa zal overgaan. Bij de SĕpatahDajaks is het geloof aan sympathetische werking reeds grootendeels verloren geraakt, daarom verklaren zij de ceremonie als een tanda $=$ teeken, symboliek. Natuurlijke symboliek is steeds ontstaan uit het geloof aan sympathetische bezwering.

De uitdrukking tali-njawa hoort men dikwijls in Landak. ${ }_{n}$ Tali nja- 


\section{$\S 25$. Symbolische beteekenis van den ring.}

Toen de Sĕpatah-Dajaks bij de Sangkings te gast waren, hadden juist dezelfde ceremoniën plats gehad.

Daarna ging men over tot de plechtige ontvangst van de Sangkings in de soerambi.

Aan de middenstijlen van het huis waren lila's gebonden en daarnaast $d j a m p a ' s$ neergezet. Voor de $d j a m p a ' s$ lagen gongs op den grond. Bij Pakoe waren de $\mathrm{dj}$ a m pa's niet gedekt geweest, bij den Toemĕnggoeng waren zij het wel. Het einde van de verzoening was toch nabij, de zaak werd hiermede afgedaan - getoetoept. Toet o e p $=$ dekken, dicht doen.

Het doel was, dat de Sangkings zich op deze gongs zouden nederzetten met een $\mathrm{dj}$ a m pa tot rugsteun, maar de Sangkings waren te bescheiden deze eeretitels aan te nemen en gingen voor de gongs op den grond zitten, waar overal matten gespreid lagen.

\section{$\S 26$. Offer an de booze geesten.}

Voordat het feest begon had de Toemĕnggoeng buiten aan de booze geesten (hantoe's) spijzen gebracht, en deze op een toempang, welke aan den ingang van de $\mathrm{kampong}$ hing, neergelegd als zoenoffer. Ook aan den agit, die onder het dak van het huis hing als vertegenwoordiger van den kemang Trio, had hij een offer gebracht om ook diens toorn af te koopen.

De ceremoniën bestonden verder in barimah, waarvoor varkens geslacht werden.

Verder vermakte men zich met mĕnariën en het bespelen der krom ong. Ook hadden telkens gezamenlijke gastmalen plaats, waaraan alle mannen aanzaten en de vrouwen de spijzen aanbrachten.

Ook werd toewa k gedronken, maar in zeer geringe hoeveelheden.

De zuidelijke Sĕpatah-Dajaks, die veel te Pontianak komen, hebben groote neiging de Maleiers in alles na te volgen. Honden worden niet meer geofferd. De kleeding is als die van Maleiers. Over het kaal geschoren hoofd dragen zij een zwart katoenen hoofddoek.

wanja tidas pandjang lagi" = zijn levensdraad loopt ten einde. "Tali njawanja soedah poetoes" = zijn levensdraad is afgesneden.

Vergelijk hiermede het geloof der Minangkabauers der Padangsche Bovenlanden, dat het hart aan een "tali njawa" hangt. Zie Animisme bij de Minangkabauers der Padangsche Bovenlanden (Bijdragen tot de Taal-, Landen Volkenkunde van Ned.-Indië, volgreeks V, deel 5, pag. 58) door van der Toorn. 
Biezen mutsjes, in Manjoeké zoo gebruikelijk, ziet men onder hen niet.

Het mĕnari-costuum was echter hetzelfde als wij elders zagen. Het bovenlijf meestal bloot of omhangen met een jasje zonder mouwen, om den hals en om het midden talrijke gordels en ketenen. $\mathrm{Om}$ het onderlijf de crinoline-sarong.

Den tweeden dag van het feest stierf een kind aan influenza, welke ziekte ook in naburige kampongs heerschte en veel slachtoffers makte. De feestelijkheden hielden toen op en de Sankings keerden huiswaarts.

$\S 27$. Geboorte-predicaten der Maleische vorstentelgen in La in a k.

Ja en Goesti zijn geboorte-predicaten, wel te onderscheiden van Pangeran, een titel, die door het Gouvernement — of Deszelfs Vertegenwoordiger, den President - verleend wordt, aan dengeen, dien de vorst tot rijksgroote (man tri) wil verheffeu. Is een vorstentelg eenmaal tot Pangeran verheven, dan wordt hij bij zijn ouden naam niet meer genoemd. Pangeran Maugkoe Boemi heette vroeger Goesti Ahmad.

Ook vorstentelgen, welke het predicaat Ja voeren, kuunen tot Pangeran worden verheven.

De zoon en de dochter vau een Pangeran of Goesti uit een huwelijk met een Oetin, (prinses van den bloede) of met eene $\mathrm{Nji}$ Mas heeten Goesti en Oetin. $\mathrm{Ja}$ is de zoon en $\mathrm{Nji}$ Mas de dochter van een Pangeran of Goesti uit een huwelijk met eene gewone kampongvrouw (orang kĕtjil).

Raden en Kjahi Agoes zijn in Landak titels van Maleische kamponghoofden.

De regeling der geboorte-predicaten is in bijna elk landschap in de Westerafdeeling van Borneo verschillend.

Het predicat Oetin wordt soms ook door mannen gedragen, in Landak echter alleen door vrouweu.

\section{$\S 28$. Regeling eener verzoening tusschen Lara} (Sambas) en Laudak Dajaks.

Bahwa inilah atocran pĕrsoempahan (moeara batoe pĕnjoegoe) ja'ni soempah kajau (potong kapala) tanam batoe mĕnoeroet adat Dajak bangsa Kĕndajan soedah dipriksa kapada kĕpala-kĕpala Dajak tiga blas batoe bĕnoewan Lara samoewanja. 
Sjahdan djoega kĕpala-kĕpala Dajak masing masing mĕnaroh tanda tangan di bawah ini.

Tanda tĕtapkĕn adat ini sabĕnĕr-bĕnĕrnja atoeran adat.

Maka dibawah inilah isjarat kĕnjataännja:

1 pĕrkara. Bĕrmoela sakalian di bĕdirikĕn satoe kĕlangkang tengkra ${ }^{5}$ badjoe) kira-kira sĕpoeloeh atau doewa poeloeh dĕpa ${ }^{5}$ djaohnja deri tĕpi soengei dimana tĕmpat akĕn bĕrsoempah itoe.

2 pěrkara. Satoe toengkat tĕnoeng di bědirikĕn sama dĕkĕt tengkra ${ }^{5}$ itoe.

3 pĕrkara. Satoe ajam boeloe poetih, satoe-satoe kĕpala mĕmbawa satoe ajam boewat tanda hati jang socdah baik di sapoekĕn kapada radja-radja dan kĕpala-kěpala Dajak jang bĕsar kĕtjil mana-mana jang ada disitoe malainkĕn di sapoekĕn itoe ajam boewat boewang toengkal pĕmalinja, habis itoe baroe disapoekĕn (kĕlangkang) tengkra ${ }^{5}$ tadi.

4 pĕrkara. Sengah, artinja satoe pinggan ditaroehkĕn diatas tengkra ${ }^{5}$ itoe.

5 pěrkara. Toempi, artinja djoewadah boendar bĕsar ditaroeh di dalam pinggan diatas tengkra ${ }^{5}$ itoe.

6 pĕrkara. Toempi, artinja djoewadah kĕtjil-kĕtjil banjaknja lima potong matjam-matjam roepanja ditaroehkěn didalam pinggan diatas tengkra ${ }^{5}$ itoe.

7 pĕrkara. Sělikat, artinja lěmĕng poeloet baujaknja lima potong pandjangnja tiga djari ditaroehkan diatas tengkra ${ }^{5}$ itoe.

8 pĕrkara. Soengkè, artinja sĕpĕrti kĕtoepat banjaknja lima pais ditaroehkěn diatas tengkra ${ }^{\circ}$ itoe.

9 pěrkara. Lima pais bidji djawa ditaroehkĕn diatas tengkra ${ }^{c}$ itoe.

10 pĕrkara. Satoe pais bidji kĕtimoen ditaroehkĕn diatas teng$\mathrm{kra}^{\mathrm{s}}$ itoe.

11 pĕrkara. Satoe pais bidji bidjian ditaroeh diatas tengkra ${ }^{\text {s }}$ itoe.

12 pĕrkara. Latoek, artinja bĕrĕtih (padi digoreng banjaknja satoe pais, ditaroeh diatas tengkras ${ }^{5}$ itoe.

13 pěrkara. Kĕlameng, artiuja boeboer antjoer banjaknja satoe pais ditaroeh diatas tengkra ${ }^{s}$ itoe.

14 perkara. Sělikat, artinja lĕmĕug poeloet djoega, pandjangnja sĕroewas boeloeh, banjaknja lima potong disandarkĕn ditengkra ${ }^{s}$ itoe.

15 pĕrkara. Toengkoes angkang, satoe boengkoes nasi ditaroehkěn diatas tengkra ${ }^{5}$ itoe.

16 pěrkara. $\mathrm{Sa}^{5} \mathrm{ja}$ njilipit, artinja satoe pais garam ditaroehkĕn diatas tengkras ${ }^{5}$ itoe. 
17 pĕrkara. Toerah siap, artinja tĕloer ajam banjaknja satoe, ditaroehkĕn diatas tengkra' ${ }^{6}$ itoe.

18 pĕrkara. Njoengan siap endek oemoer taroe wandoe, artinja satoe anak ajam oemoer tiga hari dipotong-potong tjentjang aloesaloes ditaroehkĕn diatas tengkras ${ }^{\text {itoe. }}$

19 pĕrkara. Pintik, artinja sirih lipat tjoekoep kapoer, gambir, pinang ditaroehkĕn diatas tengkras itoe.

20 pĕrkara. Sĕngaroeng, artinja satoe roewas boeloeh diïsi aër bĕtoel digantoeng dibawah tengkras itoe.

$2 l$ pĕrkara. Bĕras banjoe, artinja bras koening ditaroeh didalam satoe tjĕugkar.

22 pĕrkara. Poeloes artinja dikikis-kikis sĕgala gong dan těmpajantĕmpajan jang bĕrnama-nama dan dikikis mas dan pérak ditaroehkĕn didalam boeloeh kĕtjil-kĕtjil atau didalam tjangkir kĕtjil.

23 pĕrkara. Aloe doewa dan satoe lĕsoeng dan satoe batoe toengkoe bĕkas dipakei jang tiada tjatjatnja; itoe aloe akĕn dipakei ditatak pěrsoempahan, tatak kemang Trejo namanja.

24. pĕrkara. Petik, artinja diambil sĕdikit-sĕdikit itoe koewéhkoewéh moelai dari patsal lima sampei patsal 16 ditaroeh dalam satoe tjangker baroelah mĕmoekoel tjanang mĕmanggil Djoebatadjoebata sĕrta diamboer kaatas petik dan poeloe tadi sĕrta bĕrsoewara bĕrtrijak-trijak soewara kras, mĕmanggil sĕgala djoebata dĕngan soewara bĕrboenji sĕpĕrti Oh Djoebata Goenoeng Bawang, Djoebata Goenoeng Pědjadji, Djoebata Goenoeng Pandan, Djoebata Goenoeng Pandoeng, Djoebata Goenoeng Sigal, Djoebata Goenoeng Pĕuaring, Djoebata Goenoeng Sĕmlajoeng, Djoebata Goenong Tijong, Djoebata Goenoeng Mĕngkadang, Djoebata Toewan Radja Sambas, dan Radja Landak, Djoebata Langin, Djoebata Boelan, Djoebata Matahari, Djoebata Bintang Rĕntika, Djoebata Sĕngkaroeng, Djoebata Aër, Djoebata Tauah, Djoebata Batoe, Djocbata Kajoe, Djoebata Roemah, Djoebata Bangkene Tandjoeng Boenga, Nes Onté Kalimantěn, Soemakang, Adat Tjoepak, Mata Datjing, artiuja jang koewasa mĕndjalankan atoeran adat dalam Poelau Borneo bahroelah disěboetkěu apa-apa pěrdjandjian jang akĕn disoempahkĕn itoe.

Sjahdan bahroelah mĕmotong itoe babi dan andjing boeloe merah atau boeloe poeteh blang-blang itam djadi djoega, diděkĕt (klangkang) tengkras bĕrsama-sama ajam poeteh jaug běkas disapoekĕn pada rarlja-radja dan kĕpala-kĕpala Dajak samoeanja tĕlah sělseilah habis pĕrkaranja.

Dan lagi satoe njiroe ditaroeh dimana tengkras itoe djoewa adanja. 


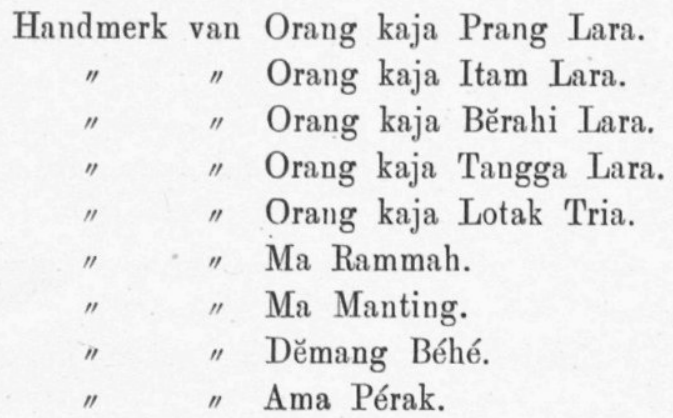

In deze regeling is geheel de adat der Lara-Dajaks gevolgd. De beteekenis van verschillende Dajaksche woorden is ons onbekend, zoodat wij in onze vertaling enkele punten in het duister moeten lateń.

\section{$\S 29$. Vertaling.}

Dit is de regeling der eedsaflegging op de pēnjoegoe ${ }^{1}$ te weten het afzweren van het snellen onder het opstellen van ( $p$ an joegoe-) steenen in den grond overeenkomstig de a dat der Kĕndajan-Dajaks - zooals die gebleken is uit een voorafgegaan onderzoek bij de hoofden van dertien afdeelingen uit het gebied van Lara.

Daarom plaatsen ook alle hoofden hun handmerk onder dit stuk, als teeken, dat hiermede die a dat naar waarheid worde vastgesteld.

Die regeling nu luidt als volgt:

$1^{0}$. Eerst richten allen te samen een klangkang op - te n gkra badjo ${ }^{2}-$ ongeveer tien of twintig vadem ver van den waterkant, op de plaats, waar men den eed doen wil.

$2^{\circ}$. Een divinatie- of wichelstok moet dicht bij de tengkra opgericht worden ${ }^{3}$.

$3^{\circ}$. Ieder hoofd moet een hoen met witte vederen medebrengen, ten teeken van een vredelievend hart; met (de vleugels van) die hoenderen moeten de aanwezige vorsten en hoofden, groote zoowel als kleine, bestreken worden om het "tongkal" en het "pamali" waarin zij verkeeren te verdrijven. Daarna moet ook de tengkras zelf bestreken worden.

\footnotetext{
1 De beteekenis van moeara in moeara batoe panjoegoe is ons niet duidelijk.

2 Tengkras - niet in woordenboek = Kĕndajansch voor klangkang.

3 Tĕnong. Deze stok zal waarschijnlijk een tak van een pelei-boom of sabang-palm geweest zijn, die door wortel te schieten en op te groeien voor den planter een lotsboom werd.
} 
$4^{\circ}$. Een sengah, dat is een aarden bord moet op de tengkras geplaatst worden.

$5^{\circ}$. Toempi, dat zijn groote ronde gebakjes moeten op dat aarden bord neergelegd worden.

$6^{\circ}$. Nog een ander soort toempi, kleine gebakjes, vijf stuks moeten op dat bord neergelegd worden.

$7^{\circ}$. Sĕlikat, dat ziju koekjes ${ }^{1}$ van kleefrijst, vijf stuks lang drie duim.

8․ So engkè, veel gelijkende op kĕtoepat ${ }^{2}$, vijf stuks.

$9^{\circ}$. Vijf pakjes tamarinde-pitjes. ${ }^{3}$

$10^{\circ}$. Een pakje met komkommerpitjes. ${ }^{4}$

$11^{\circ}$. Een pakje sesamum-pitjes. ${ }^{5}$

$12^{\circ}$. Latoek, dat is gepofte rijst, een pakje.

$13^{\circ}$. K la mèng, dat is fijngemaakte pap, een pakje, moeten op de tengkra ${ }^{5}$ neergelegd worden̨.

$14^{\circ}$. Sĕlikat, dat zijn koeken van kleefrijst in bamboe gaar gestoomd, ter lengte van eene geleding, tot een getal van vijf stuks, moeten schuin tegen de tengkras geplaatst worden.

15. Toengkoes ${ }^{6}$ angkang ${ }^{7}$, een pakje rijst.

$16^{\circ}$. Saja njilipit, dat wil zeggen, een pakje zout.

$17^{\circ}$. Toerah siap, dat wil zeggen, hoenderei, éen.

18. Njoengan siap endek ter leeftijd van taroewandoe, dat is een kuiken van drie dagen oud, fijngehakt.

$19^{\circ}$. Piutik, d. i. een sirihpruimpje geheel tot gebruik gereed met kalk, gambir en betelnoot, moeten op de tengkras neergelegd wordeu.

$20^{\circ}$. Sĕngaroeng, dat wil zeggen eene geleding bamboe gevuld met water, moet aan de tengkras opgehangen worden.

$21^{\circ}$. Bĕras banjoe, dat wil zeggen gele rijst, moet in een kopje gedaan worden.

\footnotetext{
1 Lĕmĕng - waarschijnnlijk lěmpĕng - rijstkoek (Pijnappel's woordenboek).

${ }^{2} \mathrm{~K}$ ĕtoepat - rijst gaar gestoomd in kleine kubus-vormige pakjes van kokosbladeren gevlochten.

${ }^{3}$ Bidji djawa, waarschijnlijk bidji asam djawa = tamarinde.

${ }^{4}$ Kĕtimoen = mĕntimoen = timoen = komkommer (woordenboek von de Wall).

${ }^{5}$ Bidjian - waarschïnlijk = bidjan - Jav. widjen = lĕnga = sesa$\mathrm{mum}$ - soort oliegevende plant.

6. Toengkoes = pakje rijst in bladeren gewikkeld.

7 Angkang? niet in woordenboek.
} 
22. Poeloes, dat wil zeggen afschrapsel van de gongs en tampajans, die een nam hebben, van goud en zilver moet in een bamboe-pijpje of in een kopje gedaan worden.

$23^{\circ}$. Twee stampers en een rijstblok en een treefsteen, die reeds gebruikt is, welke geen schrap of barst vertoont, om stuk gehouwen te worden bij de eedsaflegging, het in stukken houwen van deu Kemang Trio genaamd '.

$24^{\circ}$. Pĕtik, dat wil zeggen van alles cen klein weinigje genomen, te beginnen bij uummer 5 tot aan nummer 16 , dat alles in een kopje verzameld. ${ }^{2}$

Is dit alles klaar, dan pas wordt op de t j e $\mathrm{n} n \mathrm{ing}$ (muziekinstrument) geslagen, om de dewata's te roepen, en dan wordt die pĕtik en poel o e $\mathrm{e}^{\mathrm{s}}$ omhoog geworpen en met een sterk schreeuwend geluid roept men dan de goden op de volgende manier: Oh, Dewata van den Goenoeng Bawang, van den Pĕdjadji, van den G. Paudan, van den G. Pandoeng, van den G, Sigal, van den G. Pĕnaring, van den G. Sĕmlajoeng, van den G. Tijong, van den G. Mĕngkadang, ${ }^{3}$ van den Radja van Sambas en van den Radja van Landak, Dewata van den Hemel, van de Maan, van de Zon, van de Pleiaden, Dewata Sĕngkaroeng. ${ }^{+}$Dewatas van het Water, van het Land, van de Steeneu, van de Boomen, van de Huizen, Dewata Bangkéné Tandjong Boenga, ne ${ }^{5}$ Onté Kalimantěn, Soemakang ${ }^{5}$ Adat Tjoepak, ${ }^{6}$ Mata Datjing ${ }^{7}$, dat wil zeggen, die het bestuur voeren en voor het recht zorgen op het eiland Borneo.

$\mathrm{Na}$ afloop hiervan wordt pas gezegd wat men overeengekomen is onder eede te bevestigen.

Daarna gaat men er toe over een varken te slachten en een hond

1 De uitleg, dat het stukhouwen van stamper en rijstblok het dooden van den kemang Trio is, zal vermoedelijk van een Maleisch hoofd afkomstig zijn, die zulk eene verklaring in de plaats stelde van de oorspronkelijk Dajaksche.

2 In Landak toerap.

3 Namen vau bergen in Landak en Sambas.

4 Sĕngkaroeng - niet in woordenboek.

5 Bangkéné waarschijnlijk eigennaam - naam van de dewata — van de Bloemen-Tandjong (uitstekende hoek in een rivier).

$\mathrm{Ne}^{s}$ Onté Kalimantěn $=$ Grootmoeder Orang-Oetan Kalimantĕn of van Kalimantĕn. Kalimantĕn, naam van het eiland Borneo - Soemakang - niet in woordenboek.

6 Tjoepak - een mat.

7 Mata Datjing - de streepjes of sterretjes op een Chineesche unster, die het aantal kati's aanwijzen - Dewata Adat Tjoepak Mata Datjing - dewata van maten en gewichten - de Instandhouders van het Recht. 
HE'T S'TRAFRECHT DER DAJAKS VAN TAJAN EN LANDAK. 301

met roode haren; met witte haren en zwarte plekken daartusschen gaat het ook wel; het geschiedt dicht bij de teugkras (de klangkang). Ook de witte hoenders, die gebruikt zijn om de vorsten en hoofden te bestrijken worden daar ook geslacht. Is dat alles klaar, dan is de zaak daarmede afgedaan.

Dan wordt alleen nog een rijstwan boven op de tengkras gelegd. 